\title{
Achieving Environmental Sustainability in Wastewater Treatment by Phytoremediation with Water Hyacinth (Eichhornia Crassipes)
}

\author{
Tolu Olufunmilayo Ajayi ${ }^{1} \&$ Atoke Olaide Ogunbayo ${ }^{1}$ \\ ${ }^{1}$ Department of Chemical Engineering, University of Lagos, Akoka, Yaba, Lagos State, Nigeria \\ Correspondence: Tolu Olufunmilayo Ajayi, Department of Chemical Engineering, University of Lagos, Akoka, \\ Yaba, Lagos State, Nigeria. E-mail: tajayi@unilag.edu.ng
}

Received: May 22, 2012 Accepted: June 16, 2012 Online Published: June 25, 2012

doi:10.5539/jsd.v5n7p80 URL: http://dx.doi.org/10.5539/jsd.v5n7p80

\begin{abstract}
Small and medium scale industries in Nigeria play a major role in polluting water bodies, and key among these pollutants are suspended solids, biological oxygen demand and heavy metals contamination. Conventional methods of treatment, such as chemical precipitation, do not provide sustainable solutions as the pollutants are merely transferred from the waste water to a sludge residue which is disposed of by land-filling. The pollutants eventually find their way to freshwater supplies thereby contaminating it.

Water hyacinth is a noxious weed that has a rapid growth rate and easily congests the water ways in Lagos, a coastal city in Nigeria, thereby creating serious problems in navigation, and irrigation. This can be harvested, and in line with the golden rules of sustainable development, used for the sustainable treatment of some industrial wastewaters.

This work investigates the effectiveness of water hyacinth in wastewater treatment. After a 5-week simple experiment, in which water hyacinths were planted in wastewater samples obtained from three different industries, the average removal of pollutants were found to be $53.03 \%, 64.41 \%, 65.4 \%, 47.22 \%, 94.67 \%$ and $30.30 \%$ for Total Suspended Solids (TSS), Biochemical Oxygen Demand (BOD), Dissolved Oxygen (DO), nitrate-nitrogen, cadmium and iron respectively. Average Biocentration Factors (BCF) obtained for cadmium, copper and iron were $583.83,734.41$ and 2982.95 respectively.
\end{abstract}

Keywords: industrial wastewater treatment, heavy metals, sustainability, industrial ecology, phytoremediation, water hyacinth

\section{Introduction}

Fresh water is a very useful resource for the sustenance of human and industrial life, this is usually sourced from the environment and used for agricultural, industrial and domestic purposes. After use, the unwanted wastewater is normally discharged to nearby water bodies with minimal or no treatment in Lagos State, Nigeria. Due to the increase in population growth in Nigeria and the urbanization of most of her cities, there has been an increase in the number and type of industries. Along with this industrialization, is a concomitant increase in the volume of water used and consequently the quantity and quality of wastewater discharged to the water bodies in the state. These wastewaters contain toxic contaminants, which if continuously discharged to water bodies will seriously affect the marine ecosystem, fresh water supplies, and eventually human existence.

\subsection{Sustainable Development and Industrial Ecology}

Man's activities to date has been unsustainable, as all substances that sustain human life: food, water, fuels, minerals and diverse type of raw materials are all taken from the environment made use of and the unwanted waste discharged back to the environment. Man sees the environment as an unlimited source for raw materials and an unlimited sink for waste. This linear relationship (shown in Figure 1) with the environment has proved over time to be unsustainable, as most of these resources are not just non-renewable and limited, but the waste discharged back to the environment affects the purity of untapped resources, as the natural cleansing capacity of the environment can no longer cope with man's waste. 


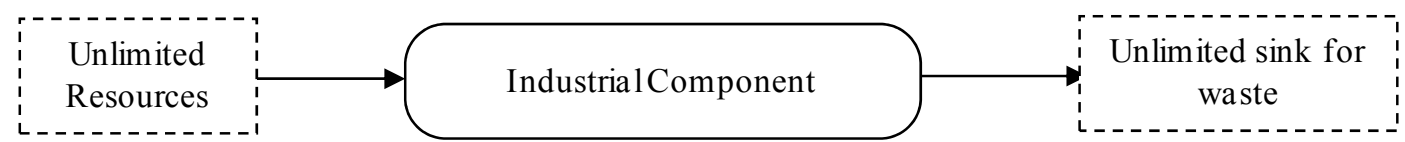

Figure 1. The unsustainable linear relationship between industries and the environment (Adapted from Garner \& Keoleian, 1995)

The United Nations World Commission on Environment and Development (Brundland, 1987) resolved that current development, while meeting the needs of people now living, should not make it difficult for future generations to meet their needs. As noted by Allenby (1999), there is the need to inculcate sustainable development into the design of industrial processes, business decisions and strategy. In the light of this, most industries have started moving away from the attitude of seeing the environment as a liability with the previous tendency to do the barest minimum to meet regulatory standards, to the modern attitude of sustainable development, where the environment is seen as an opportunity to be exploited (Bakshi, 2011).

In order to implement sustainable projects, one has to take a close look at the natural systems that, since the existence of man have been sustaining life on earth (Indigo Development, 2004). These biogeochemical cycles of carbon, nitrogen, sulphur, phosphorus etc., reveal that, as their names imply, they operate in cycles with minimal interaction with the environment. Waste from one component of the cycle is used as a resource in another component of the same cycle. The onus is therefore on industries to mimic these sustainable closed cycles of nature, if sustainable development is to be achieved. An attempt to adapt this concept of natural systems has lead to the evolution of another area of Environmental Engineering termed Industrial Ecology. Industrial Ecology seeks to change the once through approach of Figure 1 to the closed cycle approach shown in Figure 2, in which materials and energy are retained and used as many times as practicable (Indigo Development, 2004). The ultimate goal of industrial ecology is sustainable development, this work therefore examines how water hyacinth, a nuisance on our waterways can be put to beneficial use by considering the last 2Rs of the 7Rs Golden Rule to sustainable development (El-Haggar, 2007), the study does a Rethink on regarding water hyacinth as an unwanted nuisance and develops a Renovative-innovative technique whereby it can be used as a raw material for the sustainable treatment of industrial wastewater.

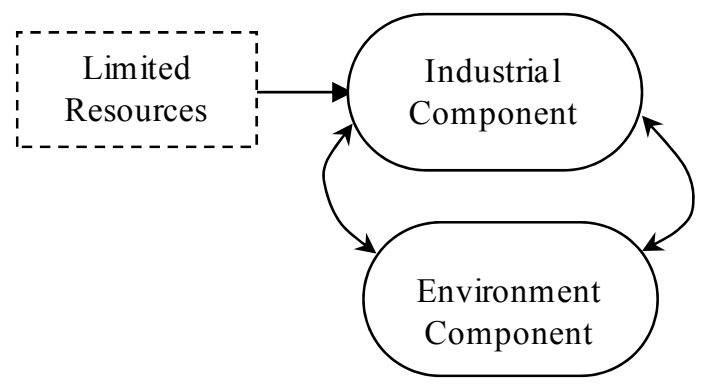

Figure 2. The sustainable closed loop relationship between industries and the environment (Adapted from Garner \& Keoleian, 1995)

\subsection{Wastewater Treatment}

In virtually all industrial operations, fresh water comes in contact with processing materials/equipments and the eventual wastewater that has to be disposed of tends to contain dissolved toxic metals. According to the World Health Organization for quality recommendations (World Health Organization [WHO], 1984) the metals of most immediate concern are cadmium, chromium, cobalt, copper, iron, lead, nickel, mercury and zinc. These heavy metals, bio-accumulate readily in marine organisms, most of which are food to man, and consequently affects man when ingested, as they are carcinogenic, interfering or injuring the growth or metabolism of cells in the body.

Current state-of-the-art techniques for the treatment of these heavy metals involve precipitating them out of the wastewater as their hydroxides, by the addition of lime or caustic, at a $\mathrm{pH}$ of minimum solubility. This process can be costly, depending on the reagent used (United Nations [UN], 2003) and these precipitates, however, still have to be disposed off, and are normally either concentrated and confined in drums for eventual disposal or just land-filled. The pollution problem has therefore not being solved but has just been transferred from one medium of the environment-water to another-land. This is therefore not a sustainable solution to the wastewater problem. 


\subsection{Water Hyacinth and Phytoremediation}

Under natural conditions, nutrients deficiency, especially of phosphorus pose a natural limiting factor for the growth of water hyacinth, but these nutrients have been supplied by human action leading to the growth of water hyacinth at a very fast rate. In Lagos, Nigeria, and its environ, sewage effluent, from municipalities and industries, which are normally rich in phosphorus, are discharged into the Lagos lagoon without adequate treatment (Don-Pedro, 2009).

For most part of the year, especially during the rainy season, there is an overpopulation of water hyacinth on most water bodies in Lagos. Water hyacinth, a floating aquatic plant-Figure 3, as been described as one of the most productive photosynthetic plant in the world, with 10 plants producing 600,000 more during an 8-month growing season and completely covering 0.4 ha ( 1 acre) of a natural freshwater surface (Winkler \& Veneman, 1991; Adebayo et al., 2011). This very rapid rate of growth is the reason water hyacinths are a serious nuisance problem in waterways, but this same attribute can become an advantage in a wastewater treatment system.

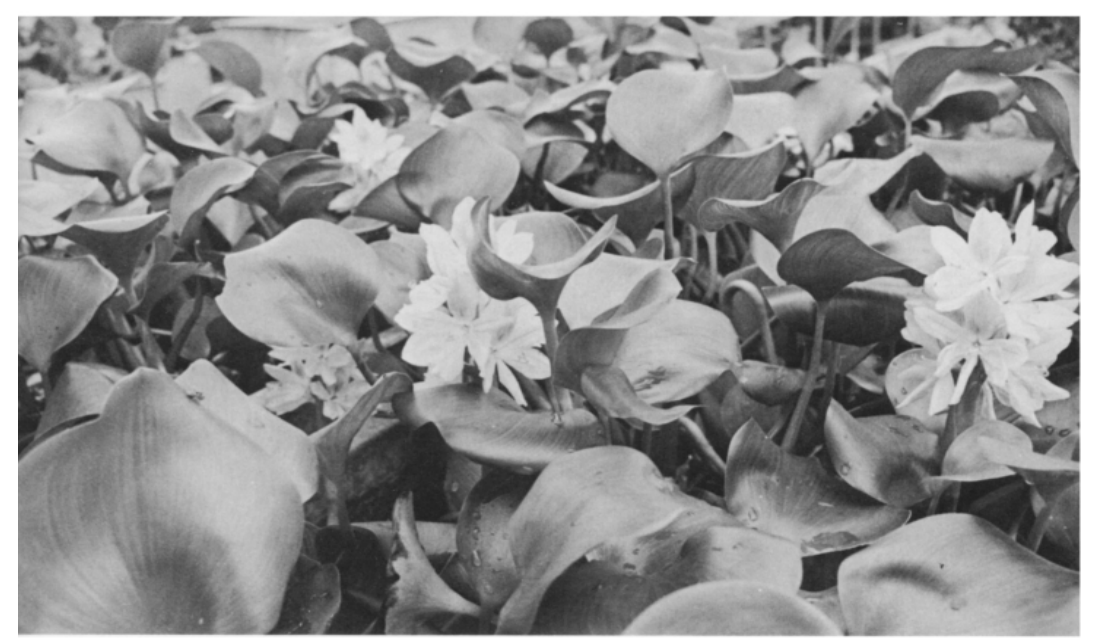

Figure 3. Water hyacinth covering the surface of a freshwater body

As reported by Chaudhuri, Salodkar, Sudarshan, Mukherjee, and Thakur (2008) and Malik (2007), a lot or authors/researchers consider water hyacinth as the world's worst aquatic plant, in that it causes various problems when it forms dense mats that cover areas of fresh water such as: hindrance to water transport, clogging of intakes of irrigation, hydropower and water supply systems; blockage of canals and rivers causing flooding; micro-habitat for a variety of disease vectors, increased evapotranspiration, killing fish and causing the reduction of biodiversity in the water body by depletion of oxygen in the water. Control and utilization technologies for water hyacinth are among others: physical removal, which can be done manually or mechanically (Gopal, 1989); chemical removal, by the use of herbicides; and biological removal by using insects which consume the hyacinths (Hong et al., 2005). But why destroy water hyacinth, when it is an "unwanted material" that can be put to beneficial use such as: production of rope and furniture; fertilisers - by either ploughing it into the ground or using it as mulch, fish feed, animal fodder, production of basket work, paper and fibre board production, biogas production and domestic wastewater treatment (Wolverton \& McDonald, 1976; Baraah \& Singh, 1984; Almoustapha et al., 2009). As discussed below, a lot of researchers have also investigated the phytoremediative abilities of water hyacinth.

Phytoremediation, has been defined as the direct usage of plants and their natural metabolic and hydraulic processes to remove, degrade or contain a contaminant (Cheremisinoff, 1996). Water hyacinths exhibit these properties and as a result, show great potential in being used in wastewater treatment systems. Studies on water hyacinth show that it improves the wastewater effluent from oxidation ponds (Polprasert \& Khatiwade, 1998) and integrated treatment systems (Liao \& Chang, 2004), and that it uses appreciable amounts of the inorganic forms of nitrogen and phosphorus found in domestic sewage, industrial and municipal wastewaters (Jayaweera et al., 2008; United Nations Environment Programme [UNEP], 2010; Nesir, 2010). Water hyacinth's quest for nutrients has also been exploited to clean wastewater in small scale sewage treatment plants where it absorbs and digests wastewater pollutants, converting sewage effluents to relatively clean water (Keith et al., 2008). It removes biochemical oxygen demand (BOD) and suspended solids (SS) when used in secondary treatment of domestic 
wastewater (Nesir, 2010) and textile mill effluents (Gamage \& Yapa, 2001). In the process of studying water hyacinth's capabilities in sewage treatment, it has been discovered that the plant is highly effective in absorbing and accumulating various heavy metals (Von, 1999) and this capability is the reason the effectiveness of water hyacinth is investigated in this study for industrial wastewater treatment by phytoremediation.

As reported by several researchers, these heavy metals are taken up by the roots of the plant and translocated to the shoots and other plant tissues, where they are concentrated (Kelly \& Guerin, 2008; Cunnigham \& Berti, 1995; Jadia \& Fulekar, 2009). Valuable heavy metals can now then be recovered by harvesting, burning and extracting the metals from the ash. According to Crawford (1999), if a plant contains $1 \%$ by weight of a metal, its ash would contain $20 \%$ by weight of that metal, a higher metal content than is found in most ores. Alternatively, the harvested water hyacinths can be used for biogas production and the non-biodegradable residue returned to the earth.

This way the plant, water hyacinth, considered as a 'nuisance' can be harvested from water bodies and used in waste water treatment, after which it can be converted to other useful products.

\section{Methods}

Water hyacinth plants were collected from one of the canals in Lagos, rinsed and transferred into a large bowl ( $45 \mathrm{~cm}$ upper, $31 \mathrm{~cm}$ lower diameter and $29 \mathrm{~cm}$ depth) containing tap water.

\subsection{Materials and Equipment}

Three identical plastic bowls were labelled A, B, and C and they were filled with the wastewater samples collected from a textile, a metallurgical and a pharmaceutical industry respectively. All the bowls were filled to a height of $16 \mathrm{~cm}$ and kept outside in the open air.

Analyses of the samples were done in the Environmental/Analytical Laboratory of the Department of Chemistry, University of Lagos, using the following equipment: $\mathrm{pH}$ meter; spectrophotometer; DO meter; and atomic absorption spectrometer and other ancillary equipment. Standard analytical procedures were followed.

Table 1. Initial characteristic of the wastewater samples

\begin{tabular}{llll}
\hline${ }^{*}$ Samples Parameters & A & B & C \\
\hline TSS, $m g / L$ & 164 & 169 & 140 \\
BOD, $m g / L$ & 0.98 & 0.6 & 1.4 \\
DO, $m g / L$ & 4.24 & 1.2 & 3.4 \\
Nitrate-Nitrogen, $m g / L$ & 40.1 & 47.8 & 33 \\
pH & 6.5 & 6.8 & 7 \\
Cadmium, $m g / L$ & 0.078 & 0.068 & 0.062 \\
Copper, $m g / L$ & 0.015 & 0.93 & Nil \\
Iron, $m g / L$ & 0.035 & 0.036 & 0.044 \\
\hline${ }^{*} \mathbf{A}$ is Textile Wastewater & & & \\
B is Metallurgical Wastewater & & \\
C is Pharmaceutical & & & \\
\hline
\end{tabular}

The initial characteristic of the wastewater before the planting of the water hyacinth is shown in Table 1.

Water hyacinth plants were then planted in the three bowls and given one week from the time planted to acclimatize to its new environment. Starting from the second week, samples were taken on a weekly basis for four weeks and analyzed for the TSS, BOD, DO, nitrogen, cadmium, copper and iron content. At the end of the 5-week experimental period, samples of the plant were taken from each bowl and the roots analyzed to determine the microbial organism present and the bioconcentration factor $(\mathrm{BCF})$ was also calculated. 


\section{Results}

Studies on the phytoremediative properties of water hyacinth in the treatment of industrial wastewater, was carried out by analysing for the following parameters:

- Biochemical oxygen demand (BOD)

- Dissolved oxygen (DO)

- Nitrate-nitrogen

- Cadmium

- Copper

- Iron

- Bio concentration factor (BCF)

- The bacterial count

\subsection{BOD}

The BOD trend shown in Figure 4, shows a similar trend in all the wastewater samples. There is an initial increase in BOD, which reaches a peak by the beginning of the $2^{\text {nd }}$ week, followed by a decreased and by the $5^{\text {th }}$ week the rate of reduction of BOD had stabilized.

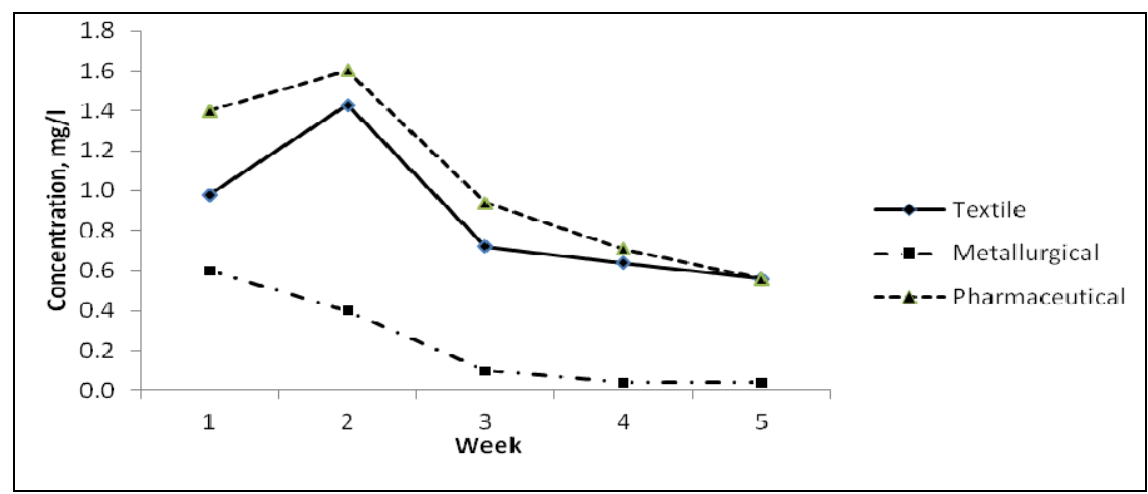

Figure 4. BOD concentration trend for the period of the experiment

\section{$3.2 \mathrm{DO}$}

As the aerobic micro-organisms around the root systems of the water hyacinth use up the oxygen available in the water samples, the oxygen available decreases, and this is depicted in Figure 5.

\subsection{Nitrate-Nitrogen}

The nitrate-nitrogen trend for the samples was observed and is shown in Figure 6. All samples exhibited a decreasing trend throughout the period of the experiment with the highest reduction occurring in the third week.

\subsection{Cadmium}

Figure 7 shows the trend for cadmium removal in the wastewater samples. There was a tremendous decrease in the cadmium concentrations especially within the first two weeks, after which change in cadmium concentration was minimal. This shows that water hyacinth is a very good plant for the phytoremediation of cadmium from water bodies. 


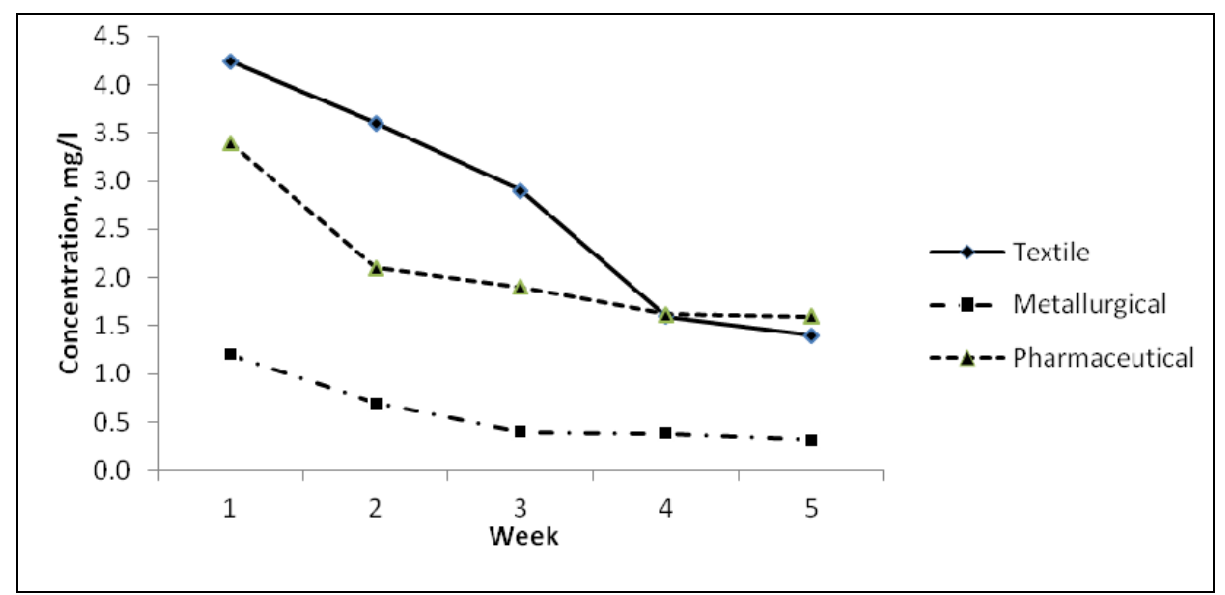

Figure 5. Dissolved Oxygen, DO concentration trend for the period of the experiment

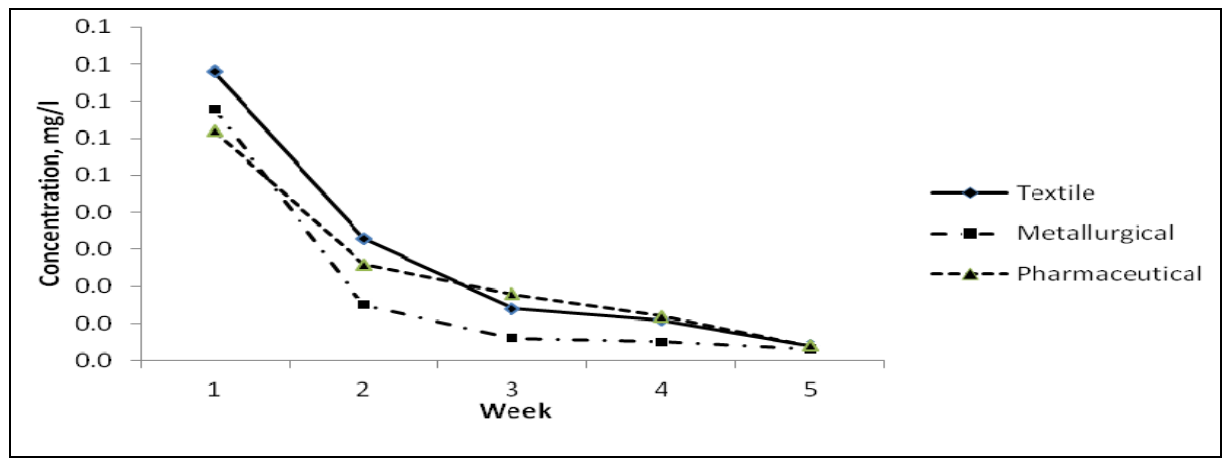

Figure 6. Nitrate-nitrogen concentration trend for the period of the experiment

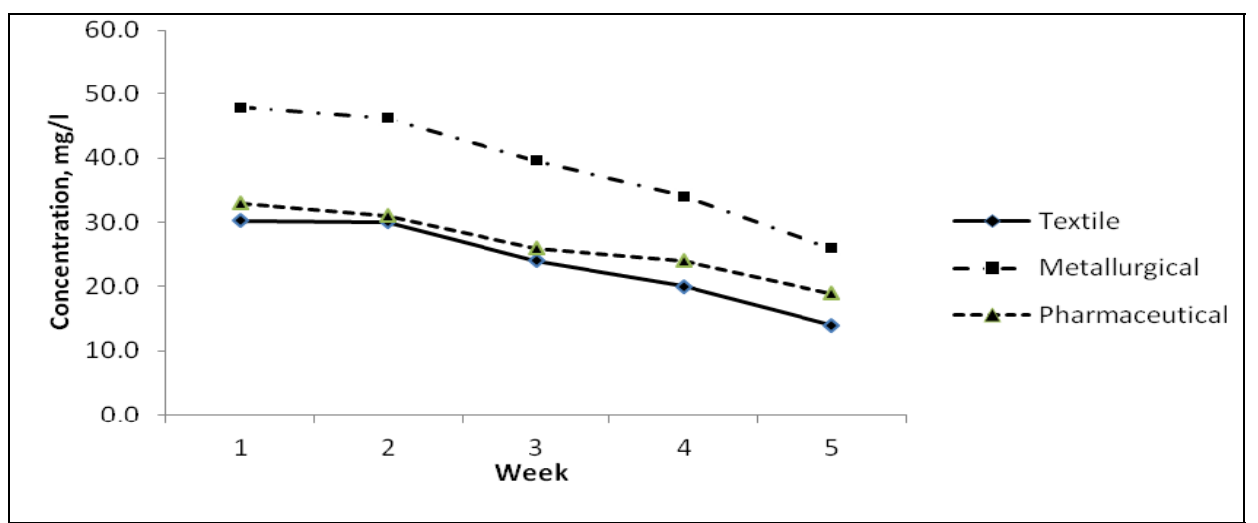

Figure 7. Cadmium concentration trend for the period of the experiment

\subsection{Copper}

The initial analysis of the water samples showed that the pharmaceutical wastewater contained no copper contaminants. However, from Figure 8, the metallurgical wastewater showed a decrease in copper concentration for every week of the experiment until the last week, where there was a very slight increase in the copper concentration.

\subsection{Iron}

The trend in iron concentration, of the samples, is shown in Figure 9. It is seen that the concentration of iron increased in the second week but subsequently decreased in the following weeks of the experiment with the highest reduction occurring in the fifth week. The textile wastewater had the highest reduction in the third week of the 
experiment, while the metallurgical wastewater had the highest reduction occurring in the fifth week. The pharmaceutical wastewater on the other hand, showed a different trend by decreasing right from the beginning of the experiment till the end and experienced the greatest reduction in the second week. It is also observed that the final concentration of the textile and metallurgical wastewaters are higher than the corresponding initial concentration while that of the pharmaceutical wastewater is lower than the initial concentration.

\subsection{BCF}

The bioconcentration factor, $\mathrm{BCF}$, which is the capability of water hyacinth to accumulate heavy metals was also calculated. It is the ratio of the metal concentration in the plant, to the concentration of metal in the wastewater, at the end of the 5 week experiment. The result is shown in Table 2 . The metallurgical wastewater had the lowest for cadmium removal but highest for Copper and Iron.

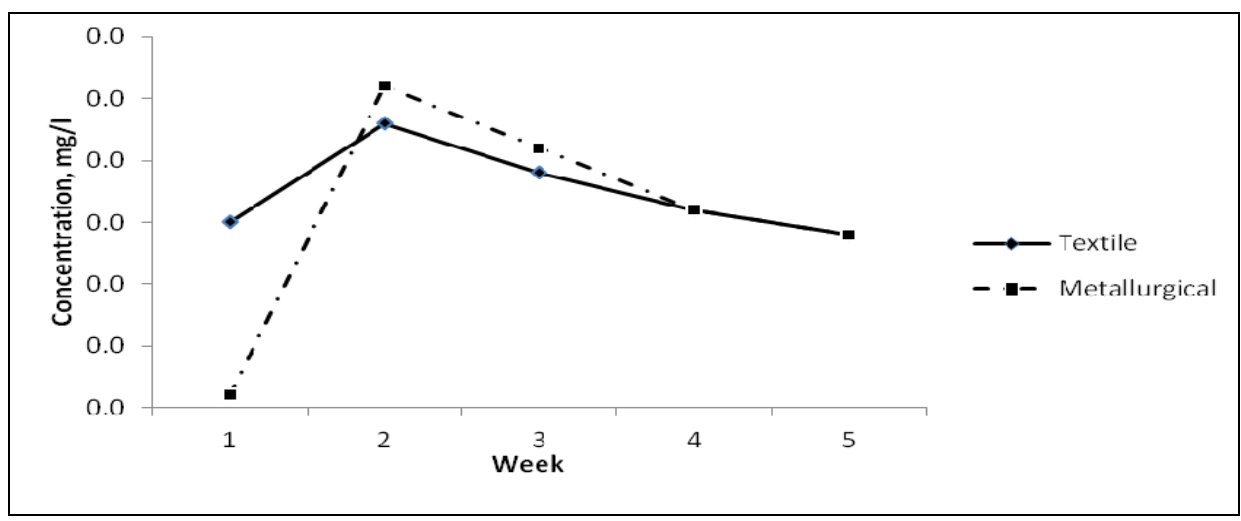

Figure 8. Copper concentration trend for the period of the experiment

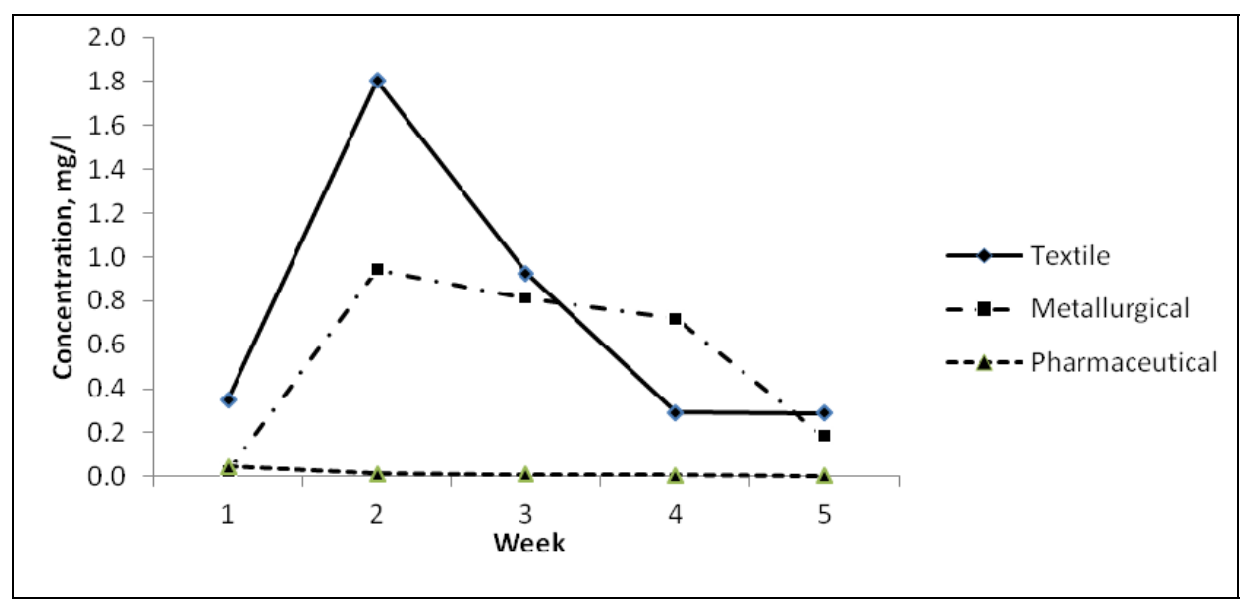

Figure 9. Iron concentration trend for the period of the experiment

Table 2. Bioconcentration factor of water hyacinth

\begin{tabular}{lcll}
\hline \multirow{2}{*}{ Parameters } & \multicolumn{3}{c}{ "Samples } \\
\cline { 2 - 4 } & $\mathbf{A}$ & $\mathbf{B}$ & $\mathbf{C}$ \\
\hline Cadmium & 439.74 & 291.18 & 388.71 \\
Copper & 233.33 & 1800 & nil \\
Iron & 3622.86 & 5022.73 & 2197.73 \\
\hline
\end{tabular}
"A is Textile Wastewater
B is Metallurgical Wastewater
C is Pharmaceutical 
Table 3. Percentage (\%) removal of pollutants from the wastewater samples

\begin{tabular}{llll}
\hline \multicolumn{1}{c}{ Samples } & \multirow{2}{*}{ A } & \multicolumn{1}{l}{ B } & \multicolumn{1}{l}{ C } \\
\cline { 1 - 3 } TSS & 31.71 & 63.91 & 63.57 \\
BOD & 66.98 & 73.33 & 52.94 \\
DO & 42.86 & 93.33 & 60 \\
Nitrate-Nitrogen & 53.64 & 45.61 & 42.42 \\
Cadmium & 94.87 & 95.59 & 93.55 \\
Copper & 6.67 & 0 & nil \\
Iron & 0 & 0 & 90.91 \\
\hline "A is Textile Wastewater & & \\
B is Metallurgical Wastewater & \\
C is Pharmaceutical & & \\
\hline
\end{tabular}

\subsection{Percentage (\%) Removal}

The results gotten from the experiment for \% removal of pollutants is shown in Table 3. The metallurgical wastewater had the highest removal for BOD, DO and cadmium while the textile wastewater had the lowest removal for DO and copper; the metallurgical wastewater did not have any copper removed and the pharmaceutical wastewater had an iron removal efficiency of $90.91 \%$.

\subsection{Identification and Characterization of Bacteria and Fungi Isolates}

Microbial analysis of the microorganisms present was done based on their morphology and biochemical characteristics using the appropriate tests and the following fungi: Aspergillus spp; Penicillium spp; Rhizopus spp; and bacteria: Micrococcus luteus; Acinetobacter; Staphylococcus aureus; Bacillus subtilis; and Pseudonomas spp were identified and believed to be responsible for the remediation of the wastewater

\subsection{Bacterial Count}

The results obtained for bacteria count is depicted in Figure 10, where a similar trend is observed for all the wastewater samples - a decrease in microbial population in the first week, followed by an increase in the second and third weeks and then a decrease in the fourth week

\section{Discussion}

The results obtained for the BOD, DO, and nitrate-nitrogen show that water hyacinth is effective for the removal of these contaminants. The \% removal for BOD in the water samples was in the order metallurgical wastewater $>$ textile wastewater $>$ pharmaceutical wastewater, for DO the order was metallurgical wastewater $>$ pharmaceutical wastewater $>$ textile wastewater and for nitrate-nitrogen, the order was textile wastewater $>$ metallurgical wastewater $>$ pharmaceutical wastewater. The average $\%$ removal was $54.80,62.64$, and 48.57 for BOD, DO, and nitrate-nitrogen respectively and these values indicate the usefulness of water hyacinth plant for reducing the level of these contaminants in contaminated water. The initial increase in the level of BOD on planting the water hyacinth cannot be explained as of now.

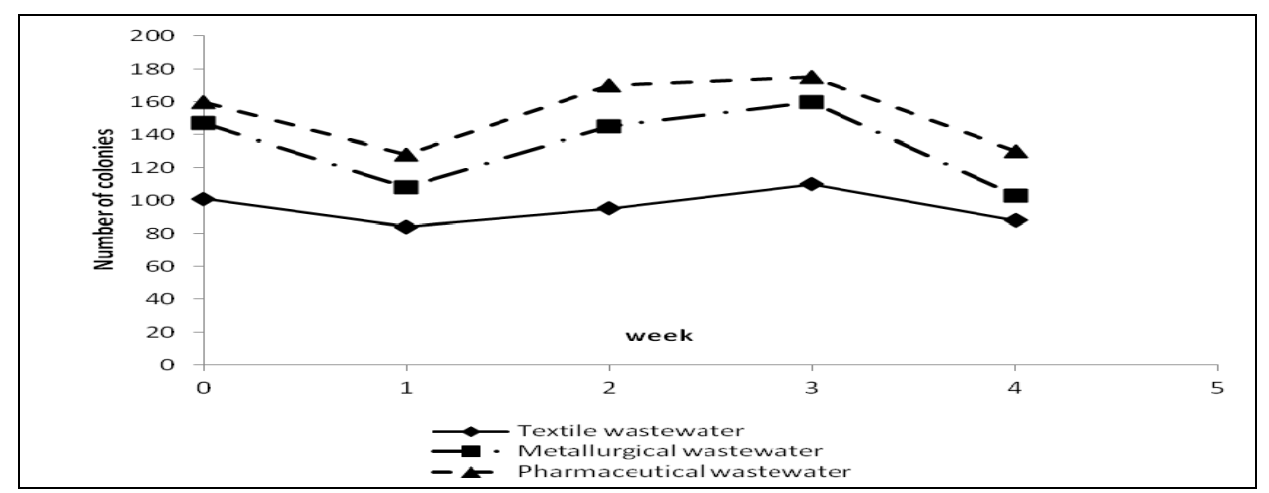

Figure 10. Total bacteria count for the period of the experiment 
Water hyacinth seems to be a good choice for removing cadmium but not so much for the removal of iron and copper. During the 5 weeks duration of the experiment, the plant removed $94.87 \%$ in the textile wastewater, $95.59 \%$ in the metallurgical wastewater and $93.55 \%$ in the pharmaceutical wastewater. The longer the water hyacinth stayed in the plant, the lesser the amount of cadmium taken up by the plant. This could be attributed to the lack of plant harvesting during the experimental period. Lu, Kruatrachue, Pokethitiyook, and Homyok (2004) deduced that water hyacinth could be used to treat water contaminated with low cadmium concentrations. The copper data showed directly opposite results when compared to cadmium. It seems that when a plant such as water hyacinth is in the presence of really low amounts of copper, levels of copper in water are greater than when copper is present without any plants. The trends exhibited by the textile and metallurgical wastewaters attest to this, the concentration increasing when the plants were planted and post analysis concentrations of copper in the water samples were close to the beginning concentrations of copper. Keith et al. (2008) found that root exudates from the water hyacinth could have kept copper soluble or suspended in water, thus showing higher concentration of copper in the samples. The metallurgical wastewater did not experience any copper removal during the duration of the experiment. The average \% removal of copper was 14.05 which show that water hyacinth is not a good choice for the removal of copper from contaminated water. The result of iron showed a marked resemblance to that of copper for all the water samples except the pharmaceutical wastewater which had the highest initial concentration of iron. Post analysis concentration showed that the final concentrations were higher than the initial concentrations in the water samples excluding the pharmaceutical wastewater which had a $90.91 \%$ removal of iron. Another reason for the inefficiency of water hyacinth in removing iron from the water samples might be due to the presence of other nutrients, in this case, present as nitrate-nitrogen. Jayaweera et al. (2008) concluded in their study that water hyacinths grown under nutrient-poor conditions are ideal to remove iron from wastewaters.

The $\mathrm{pH}$ of the water samples were taken during the duration of the experiment on a weekly basis and it was noticed that the $\mathrm{pH}$ had decreased by the end of the experiment. Optimal reduction of contaminants was noticed to have occurred when the $\mathrm{pH}$ was within the range 5.4-7.0. The colour and odour of the water samples were noticed to have improved also by the end of the experiment.

The appropriateness of a plant for phytoremediation potential is often judged by its Bioconcentration factor (BCF). BCF values over 1000 are generally considered evidence of a useful plant for phytoremediation (Zhu et al., 1999). The BCF value for cadmium was above 1000, indicating that water hyacinth is a good accumulator of this metal.

Bacterial growth for the textile wastewater was the lowest of the three wastewater samples. This could have been as a result of the high concentration of cadmium. Soltan and Rashed (2003) reported in their work that cadmium was toxic and caused substantial reduction in water hyacinth growth, mainly by suppressing development of new roots.

\section{Conclusion}

Water hyacinth was able to significantly reduce the pollution load of textile, metallurgical, and pharmaceutical wastewaters, with respect to the removal of BOD, DO, TSS, nitrate-nitrogen and cadmium, but was of little or no value in the case of copper and iron. Reduction was highest in the pharmaceutical wastewater followed by the metallurgical wastewater and lastly the textile wastewater. Water hyacinth was most efficient for the removal of cadmium and least efficient for copper and iron in this study. The BOD, DO, TSS, nitrate-nitrogen, cadmium and copper reductions ranged from $41.94 \%$ - 52.94\%, 42.86\% - 93.33\%, 42.42\% - 53.64\%, 31.71\% - $63.91 \%, 87.69 \%$ $-95.59 \%$ and $6.67 \%-35.48 \%$ respectively with iron reduction occurring in the pharmaceutical wastewater only with a reduction of $90.91 \%$. It can therefore be concluded that water hyacinths are not very effective for copper and iron removal from industrial wastewaters.

The BCF of water hyacinth in this study indicate that it is a good accumulator of iron with an average BCF value of 2982.95 and a moderate accumulator for cadmium and copper with average BCF values of 586.83 and 734.41 respectively.

In conclusion, water hyacinth, considered as a 'nuisance' can be harvested from water bodies and used in waste water treatment, after which it can be converted to other useful products. This process can be established at a fraction of the cost required for a conventional treatment system even though will most likely require more land and produce large plant biomass for which utilization skills such as biogas production, and/or precious metal recovery or other uses can be devised, very unlike the conventional methods that produce waste that still has to be discharged to the environment. Phytoremediation, using water hyacinth, is economically viable, ecologically suitable and socially acceptable, and can therefore be said to be a more sustainable method for industrial waste water treatment. 


\section{References}

Adebayo, A. A., Briski, E., Kalaci, O., Hernandez, M., Ghabooli, S., Beric, B., ... MacIsaac, H. J. (2011). Water hyacinth (Eichhornia Crassipes) and water lettuce (Pistia Stratiotes) in the Great lakes: playing with fire? Aquatic Invasions, 6(1), 91 - 96. http://dx.doi.org/10.3391/ai.2011.6.1.11

Allenby, B. R. (1999). Industrial Ecology, Policy Framework and Implementation. Englewood Cliffs, New Jersey: Prentice Hall.

Almoustapha, O., Kenfack, S., \& Rasolodinby, J. M. (2009). Biogas production using water hyacinths to meet collective energy needs ina Sahelian country. Fields Action Science Reports, 2, 27-32. Retrieved from http://www.field-actions-ssci-rep.net//27/2009

Bakshi, B. R. (2011). The path to a sustainable chemical industry: progress and problems. Current Opinion in Chemical Engineering, 1, 64-68. http://dx.doi.org/10.1016/j.coche.2011.07.004

Baraach, J. N., \& Singh, H. D. (1984). An environmentally sound scheme for the management of water hyacinth through its utilization. Proceedings of the International Conference on Water Hyacinth, 96-125.

Brundtland, G. H. (1987). Our Common Future: The World commission on Environment and Development. Oxford: Oxford University Press.

Chaudhuri, S. R., Salodkar, S., Sudarshan, M., Mukherjee, I., \& Thakur A. R. (2008). Role of water hyacinth-mediated phytoremediation in waste water purification at east Calcutta wetland. Environmental Sciences, 5(1), 53-62. http://dx.doi.org/10.1080/15693430701833427

Cheremisinoff, N. P. (1996). Biotechnology for waste and wastewater treatment. William Andrew Publishing.

Crawford, R. L. (1999). Encyclopaedia of bioprocess Technology - Fermentation, Biocatalysis, and Bioseparation (pp. 424-432). Edited by Flickinger, MC and SW Drew John Wiley.

Cunnigham, S. D., \& Berti, W. R. (1995). In Hinchee, R. E., Means, J. L., \& Burris, D. R. (Eds.), Bioremediation of Inorganics (pp. 33-54). Battelle Press, Columbia, Ohio.

Don-Pedro, K. N. (2009). Man and the Environmental Crisis (pp. 28-29). University of Lagos Press.

El-Haggar, S. M. (2007). Sustainable Industrial Design and Waste Management (pp. 12-13). London: Elsevier Academic Press.

Gamage, N. S., \& Yapa, P. A. J. (2001). Use of water hyacinth [Eichhornia crassipes (mart) solms] in treatment systems for textile mill effluents - A case study. J. Natn. Sci. Foundation, Sri Lanka, 29(1 \& 2), 15-18.

Garner, A., \& Keoleian, G. A. (1995). Industrial Ecology: An Introduction, National Pollution Prevention Center for Higher Education (pp. 11). University of Michigan, Ann Arbor, Michigan. Retrieved from http://www.umich.edu/ nppcpub/resources/compendia/INDEpdfs/INDEintro.pdf

Gopal, B. (1989). Aquatic Plant Studies 1 (pp. 360-366). New York: Water Hyacinth Elsevier Science Publishing Company.

Hong, C-1, Wei, Y-z, Jia, Y-b, Yang, X-e, \& Weng H-x. (2005). The advances of water hyacinth for control and overall utilization studies. Bulletin of Science and Technology, 2005 -04 China National Knowledge Infrastructure, CNKI.

Indigo Development. (2004). Creating Systems Solution for Sustainable Development through Industrial Ecology. Retrieved from http://www.indigodev.com/IE.html

Jadia, C. D., \& Fulekar, M. H. (2009). Review on phytoremediation of Heavy Metals: Recent Techniques. African Journal of Biotechnology, 8(6), 921.

Jayaweera, M. W., Kasturiarachchi, J. C., Kularatne, R. K., \& Wijeyekoon, S. L. (2008). Contribution of Water Hyacinth (Eichhornia Crassipes) grown under different Nutrient Conditions to $\mathrm{Fe}$ - removal Mechanisms in Constructed Wetlands. J. Environ Manage, 87(3), 450-460. http://dx.doi.org/10.1016/j.jenvman.2007.01.013 PMid:17383797

Keith, C. H., Borazjani, S. V. D., \& Baldwin, B. S. (2008). Removal of Copper, Chromium and Arsenic by Water Hyacinths (pp. 15-19). 36th Annual Mississippi Water Resources Conference.

Kelly, R. T., \& Guerin, T. F. (1995) In Hinchee, R. E., Means. J. L., \& Burris, D. R. (Eds.), Bioremediation of Inorganics (pp. 25-32). Columbia, Ohio: Battelle Press. 
Liao, S. W., \& Chang, W. L. (2004). Heavy Metal Phytoremediation by Water Hyacinth at Constructed Wetlands in Taiwan. Aquatic Plant Management, 42, 60-61.

Lu, X., Kruatrachue, M., Pokethitiyook, P., \& Homyok, K. (2004). Removal of Cadmium and Zinc by Water Hyacinth, Eichhornia crassipes. Science Asia, 30, 93-103. http://dx.doi.org/10.2306/scienceasia1513-1874.2004.30.093

Malik, A. (2007). Environmental Challenge vis a vis opportunity: The case of water hyacinth. Environmental International, 33(1), 122-138. http://dx.doi.org/10.1016/j.envint.2006.08.004

Nesir, N. (2010). Potential Use of Water Hyacinth (E. Crassipes) for Wastewater Treatment in Serbia. Retrieved from www.balwois.com/balwois/administration/full-paper/ffp-623.pdf

Polprasert, C., \& Khatiwade, M. R. (1998). An Integrated Kinetic Model for Water Hyacinth Ponds used for Wastewater Treatment. Water Research, 32(1), 179-185. http://dx.doi.org/10.1016/S0043-1354(97)00191-7

Soltan, M. E., \& Rashed, M. N. (2003). Laboratory study on the survival of water hyacinth under several conditions of heavy metal concentrations. Advances in Environmental Research, 7(2), 321-334. http://dx.doi.org/10.1016/S1093-0191(02)00002-3

United Nations, UN. (2003). Wastewater Treatment Technologies: A General Review. United Nations, New York, NY.

United Nations Environment Programme, UNEP. (2010). Sourcebook of Alternative Technologies for Freshwater Augmentation in West Asia, Case Study 8: Wastewater Treatment using Water Hyacinth in Iraq. Retrieved from www.unep.or.jp/ietc/publications/techpublications/Iraq/.asp

Winkler, E. S., \& Veneman, P. S. M. (1991). A Denitrification System for Septic Tank Effluent using Sphagnum Peat Moss in Proceedings of the 6th National Symposium on Individual and Small Community Sewage Systems, American Society of Agricultural Engineers (ASAE), 155.

World Health Organization, WHO. (1984). Guideline for drinking water quality recommendations, Vol. 1. Geneva

Von, W. N., Klair, S., Bansal, S., Briat, J. F., Khodr, H., Shiori, T., ... Hider, R. (1999). Nicotianamine Chelates both $\mathrm{Fe}$ (III) and Fe (II). Implications for Metal Transport in Plants. Plant Physiol, 119, 1109-1111. http://dx.doi.org/10.1104/pp.119.3.1107

Zhu, Y. L., Zayed, A. M., Qian, J. H., Desouza, M., \& Terry, N. (1999). Phytoaccmulation of trace elements by wetland plants: II. Water Hyacinth. Journal of Environmental Quality, 28, 339-344. 